\title{
Cytogenetics of Imparfinis schubarti (Siluriformes: Heptapteridae) from the Piumhi drainage, a diverted river in Minas Gerais State, Brazil
}

\author{
Daniel L. Z. Kantek 1, 3; Wellington A. M. Peres '; Paulo A. Buckup ${ }^{2} \&$ Orlando Moreira-Filho ${ }^{1}$ \\ ${ }^{1}$ Laboratório de Biodiversidade Molecular e Citogenética, Departamento de Genética e Evolução, Universidade Federal de \\ São Carlos. 13566-430 São Carlos, São Paulo, Brasil. E-mail: daniel_kantek@hotmail.com \\ 2 Departamento de Vertebrados, Museu Nacional, Universidade Federal do Rio de Janeiro. Quinta da Boa Vista, \\ 20940-040 Rio de Janeiro, Rio de Janeiro, Brasil. \\ ${ }^{3}$ Corresponding author.
}

\begin{abstract}
Specimens of Imparfinis schubarti (Gomes, 1956) collected in the Piumhi river drainage, state of Minas Gerais, Brazil, were studied cytogenetically. The river was diverted from the Rio Grande Basin into the São Francisco basin in the early 1960s. All individuals presented $2 n=58$ chromosomes, including 18 metacentric, 34 submetacentric and six subtelocentric chromosomes. A secondary constriction was observed in the interstitial region of the long arm of the largest chromosome pair, coinciding with the NOR. A single conspicuous heterochromatic block located in the largest pair of metacentric chromosomes was observed, adjacent to the secondary constriction. A detectable $18 \mathrm{~S}$ rDNA probe hybridization region occurs in only one chromosome pair and is synthenic with the marking obtained with $5 \mathrm{~S}$ rDNA probe. These results fit the cytogenetic pattern previously described for the genus Imparfinis Eigenmann \& Norris, 1900.
\end{abstract}

KEYWORDS. Transposed river; subclade nemuroglanis; FISH; São Francisco River Basin.

LUNDBERG et al. (1991a, b) divided Pimelodidae into presumably monophyletic subfamilies, Pseudopimelodinae and Rhamdiinae, suggesting that the family is not monophyletic in its traditional definition. The hypothesis of Pimelodidae polyphyly was corroborated by PINNA (1998) based on phylogenetic studies of the order Siluriformes. PINNA (1998) also demonstrated the priority of the name Heptapterinae over Rhamdiinae. BocKMANN \& GUAZZELLI (2003) elevated Heptapterinae to the category of family, including 190 species and 24 genera. Subclades of Heptateridae have been recognized in the literature based on morphological data (Ferraris 1998, Lundberg et al. 1991a, BocKMANN 1994), and Imparfinis has been included in the so-called Nemuroglanis subclade, along with thirteen other genera: Acentronichthys Eigenmann \& Eigenmann, 1889, Cetopsorhamdia Eigenmann \& Fisher in Eigenmann, 1916, Chasmocranus Eigenmann, 1912, Heptapterus Bleeker, 1858, Horiomyson Stewart, 1986, Imperales Schultz, 1944, Medemichthys Dahl, 1961, Nannorhamdia Regan, 1913, Nemuroglanis Eigenmann \& Eigenmann, 1889, Pariolius Cope, 1872, Phenacorhamdia Dahl, 1961, Phreatobius Goeldi, 1905, and Rhamdiopsis Haseman, 1911.

Imparfinis, with 18 valid species (BocKMANN \& GUAzzelLI 2003), is one of the least phylogenetically resolved groups of Heptapteridae (BocKMANN 1994). Species of Imparfinis inhabit the headwaters of rivers from Central America and the tropical areas of South America. They are of small in size and have benthic and nocturnal habits (CASTRO \& CASSATI 1997).

Up to this moment, six species of Imparfinis have been studied cytogenetically: Imparfinis mirini Haseman, 1911, with
$2 \mathrm{n}=58 ;$ I. borodini Mees \& Cala, 1989, with $2 \mathrm{n}=52 ;$ I. piperatus Eigenmann \& Norris, 1900, with 2n = 58; Imparfinis sp. cf. $I$. piperatus with $2 \mathrm{n}=56$; Imparfinis sp. aff. . schubarti with $2 \mathrm{n}=$ 58; and I. hollandi Haseman, 1911 with $2 \mathrm{n}=42$ (Tab. I). In these species there is a predominance of metacentric and submetacentric chromosomes and a simple interstitial NOR.

In this paper we describe the karyotype of a population of I. schubarti from the Piumhi River basin.

The River Piumhi, a tributary of the River Rio Grande in state of Minas Gerais, Brazil, was diverted in the 1960s from the Rio Paraná basin into the São Francisco basin. During construction of the Furnas hydroelectric dam in the Rio Grande, a secondary dike was built in the lower course of the River Piumhi in order to raise the water volume of the Furnas Dam and to avoid the flooding of the town of Capitólio. This secondary damming required the deviation of the Piumhi from the Rio Grande drainage into the São Francisco basin (Moreira-FilHo \& BucKup 2005) (Fig. 1). This study is part of a comprehensive investigation on the mixture of Paranean and San Franciscan fish faunas that resulted from the diversion of the River Piumhi.

\section{MATERIAL AND METHODS}

Ten specimens (four males and six females) collected in the Ribeirão Minhocas (20³1'55.2”S, 46 $\left.02^{\prime} 42.1^{\prime \prime} \mathrm{W}\right)$, a small tributary of the River Piumhi (Fig. 1), were cytogenetically studied in this work. Voucher specimens are deposited in the Ichthyological Collection of the National Museum under number MNRJ 29336 (2 specimens) and MNRJ 32759 (8 specimens). 


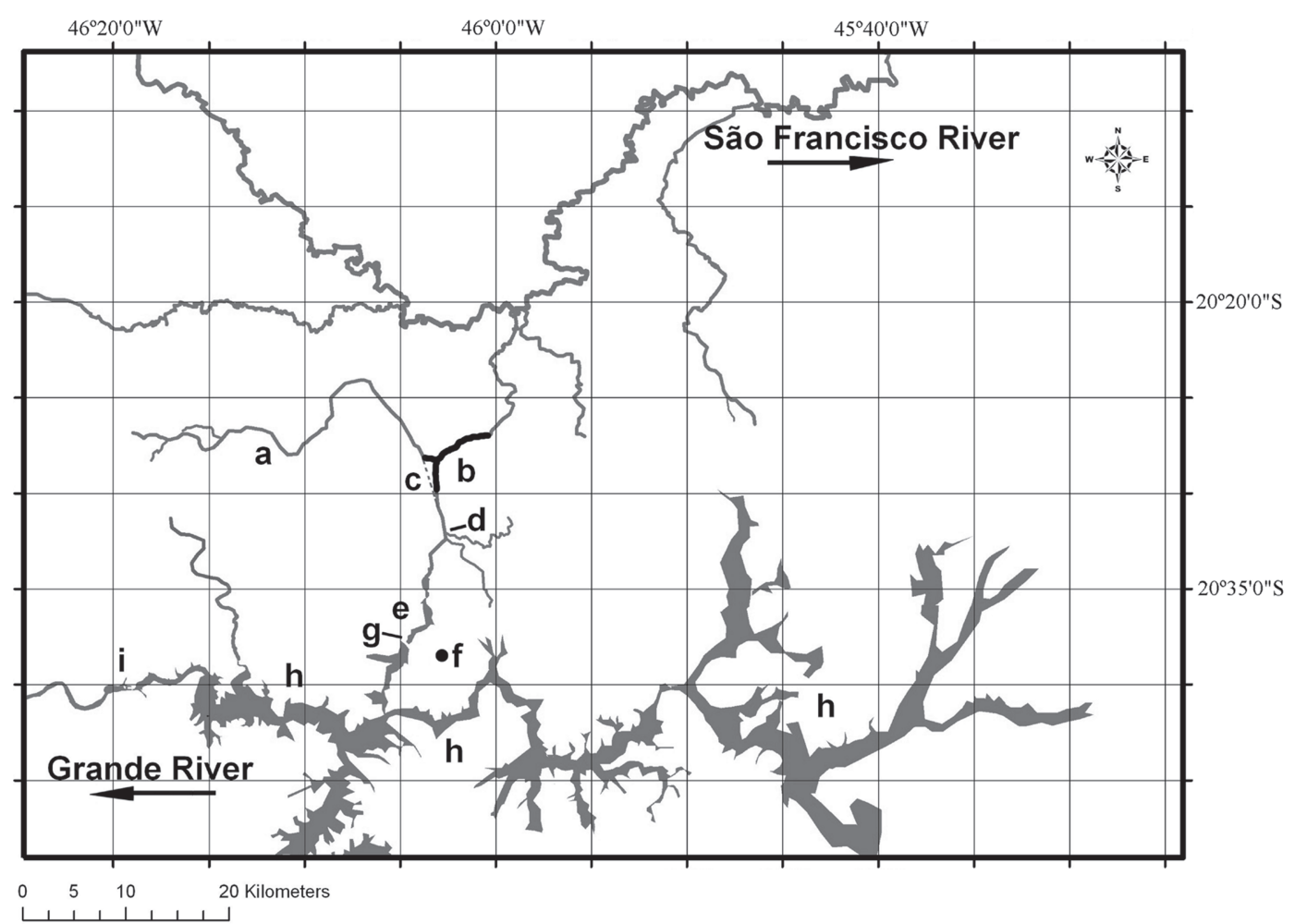

Figure 1. Transposition region of the Piumhi river: a) Piumhi River, b) transposition channel (thick black lines), c) old channel of the Piumhi River (dashed line), before the transposition, d) collection site, e) portion of Piumhi River dammed after construction of the dike near Capitólio, f) Town of Capitólio, g) Capitólio dike, h) Furnas Lake, and i) Grande river downstream from the Furnas hydroelectric dam.

The mitotic metaphases were obtained according to BerTollo et al. (1978) and Foresti et al. (1993). Chromosome morphology was determined according to the arm size relation proposed by Levan et al. (1964). The fundamental number (FN) was established through the sum of the number of chromosome arms, counting two arms for metacentric (m), submetacentric (sm), and subtelocentric (st) chromosomes, and one arm for acrocentric (a) chromosomes. The constitutive heterochromatin was identified using the barium hydroxide method (SumNer 1972), and the nucleolar organizing regions were detected through silver nitrate staining (HowELL \& BLACK 1980). Each preparation was stained in conventional Giemsa staining, and subsequently submitted to C-banding.

The location of the $18 \mathrm{~S}$ and 5S rDNA sites in the chromosomes was performed using the Fluorescence in situ Hibridization (FISH) technique (PINKEL et al. 1986), with 77\% stringency and probes obtained from Prochilodus argenteus Spix \& Agassiz, 1829 (Hatanaka \& Galetti JR 2004) and Leporinus elongatus Valenciennes, 1850 (Martins \& GaletTI JR 1999), respectively. The probes were marked with 14-dATP-biotin by nick translation according to the manufacturer's instructions (Bionick Labelling System - Invitrogen). The chromosomes were counterstained with DAPI $(0.2 \mathrm{mg} / \mathrm{ml})$ and analyzed in an
Olympus BX50 epifluorescence microscope. The software Image-Pro Plus (Media Cybernetics) was used for image capture.

\section{RESULTS}

The samples presented $2 \mathrm{n}=58$ chromosomes with $18 \mathrm{~m}$ $+34 \mathrm{sm}+6 \mathrm{st}$ (Fig. 2) and a fundamental number of 116. No gender-related chromosomal differences were observed. A conspicuous secondary constriction coinciding with the Ag-NOR was observed in the interstitial region of the long arm of the first submetacentric chromosome pair. Differences in the sites obtained through silver nitrate impregnation between the chromosomes of pair 1 were often observed (Fig. 3). The chromosomes have low quantities of constitutive heterochromatin, except for the first pair of submetacentric chromosomes, which has a large heterochromatic block adjacent to the secondary constriction (Fig. 3).

Fluorescence in situ hybridization with $18 \mathrm{~S}$ rDNA probes produced markings that coincided with the AG-NORs located in the secondary constriction of the first pair of sub metacentric chromosomes. These markings were heteromorphic between homologous chromosomes (Fig. 4). The 5S rDNA FISH markings were synthenic with those for $18 \mathrm{~S}$ rDNA (Fig. 5). 

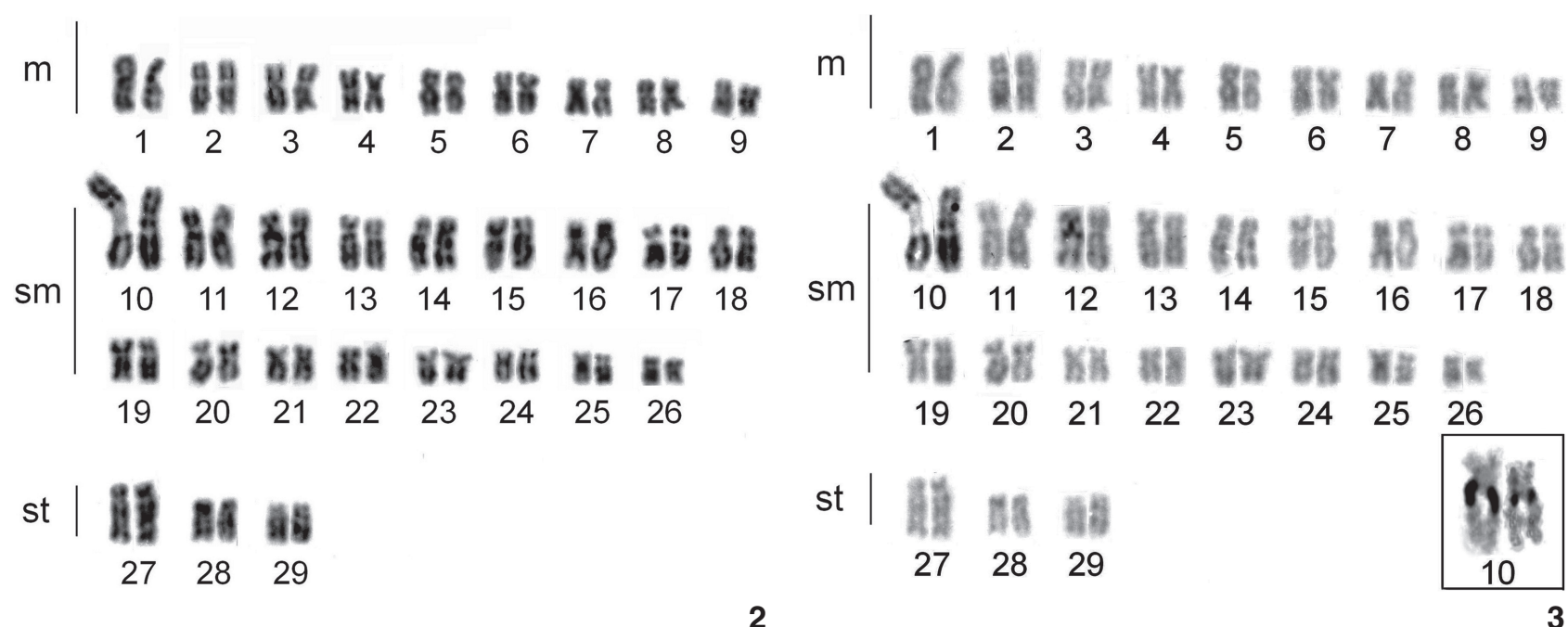

2

Figures 2-3. Karyotypes of Imparfinis schubarti: (2) Giemsa stain and (3) C-band. In the box, interstitial Ag-NOR in the largest chromosome pair.
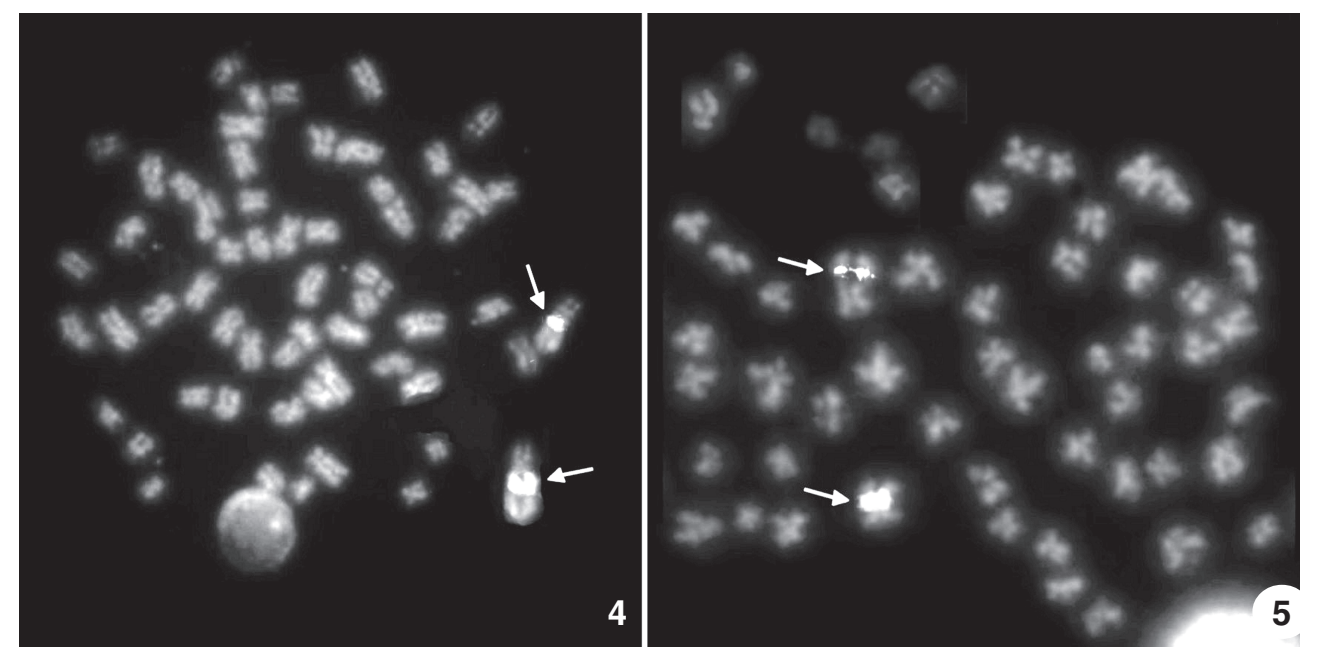

Figures 4-5. Imparfinis schubarti metaphases. Chromosomal distribution (4) of the 18S rDNA and (5) of the 5S rDNA sites.

\section{DISCUSSION}

The $2 \mathrm{n}=58$ karyotype identified in $I$. schubarti is the most common diploid number among species of Imparfinis (Tab. I), as well as within the entire order Siluriformes (Oliverra et al. 1988). Species of Imparfinis, as most Siluriformes, are also characterized by predominance of metacentric and submetacentric chromosomes and high fundamental number (FN) values. These features correspond to plesiomorphic conditions that are widely distributed throughout the order (OliveIRA \& GosZTONYI 2000). The FN = 116 , found in $I$. schubarti, is the most common in the genus, being present also in I. piperatus (VIssotто et al. 2001), I. mirini (VISSOTто et al. 1997) and Imparfinis sp. aff. I. schubarti (STOLF et al. 2004).
Simple nucleolar organizing regions located in the largest chromosome pair coinciding with interstitial secondary constrictions and $2 \mathrm{n}=58$ are characteristics present in I. schubarti, $I$. mirini, I. piperatus-cytotypes A and B, and Imparfinis sp. aff. I. schubarti (Tab. I). If $2 \mathrm{n}=58$ is a plesiomorphic condition as suggested by Oliveira et al. (1988) and Fenocchio et al. (2003), a reduction in the number of chromosomes may be a synapomorphy grouping Imparfinis sp. cf. I. piperatus from the Juquiá River (Vissotto et al. 2001, Fenocchio et al. 2003), I borodini (MARGARIDO \& Moreira-Filho 2008) and I. hollandi (Vissotto et al. 1999). This hypothesis is corroborated by the repositioning of the nucleolar organizing region in these species from chromosome pair 1 to other pairs in these species. Additionally, the migration of the 
Table I. Cytogenetic data avaliable for Imparfinis spp.

\begin{tabular}{|c|c|c|c|c|c|}
\hline Species & Locality, State & $2 n$ & Karyotype & NOR & References \\
\hline I. hollandi & Iguaçu river, PR & 42 & $8422 m+10 s m+10 s t$ & pair 18 - terminal - st & $\begin{array}{l}\text { MARGARIDO \& MOREIRA- } \\
\text { FILHO (2008) }\end{array}$ \\
\hline Imparfinis borodini * & Quinta stream, SP & 52 & $11622 m+26 s m+4 s t$ & two pairs - terminal & VIssotтo et al. (1999) \\
\hline I. piperatus cyt. A & Araras river, SP & 58 & $11632 \mathrm{~m}+26 \mathrm{sm}$ & pair 1 - interstitial - m & Vissotto et al. (2001) \\
\hline I. piperatus cyt. B & Grande river, SP & 58 & $10626 m+22 s m+8 s t+2 a$ & pair 1 - interstitial - m & Vissotto et al. (2001) \\
\hline Imparfinis cf. piperatus & Juquiá river, SP & 56 & $10822 m+26 s m+4 s t+4 a$ & pair 28 - interstitial - a & Vissotto et al. (2001) \\
\hline Imparfinis cf. piperatus & Juquiá river, SP & 56 & $11224 m+12 s m+20 s t$ & pair 22 - interstitial - st & FENOCCHIO et al. (2003) \\
\hline I. mirini & Jacutinga stream, SP & 58 & $11624 m+34 s m$ & pair 1 - interstitial - m & VIssotto et al. (1997) \\
\hline I. mirini & Jacutinga stream, SP & 58 & $11624 m+34 s m$ & pair 1 - interstitial - m & VIsSOTto (2000) \\
\hline I. mirini & Alambarí river, SP & 58 & $11624 \mathrm{~m}+34 \mathrm{sm}$ & pair 1 - interstitial - m & Vissotto (2000) \\
\hline I. mirini & Capivari river, SP & 58 & $11624 m+34 s m$ & pair 1 - interstitial - m & Vissotto (2000) \\
\hline I. mirini & Três Barras stream, SP & 58 & $11624 m+34 s m$ & pair 1 - interstitial - m & Vissotto (2000) \\
\hline I. mirini & Quinta stream, SP & 58 & $11624 m+34 s m$ & pair 1 - interstitial - m & Vissotto et al. (1997) \\
\hline I. mirini & Quinta stream, SP & 58 & $11624 \mathrm{~m}+34 \mathrm{sm}$ & pair 1 - interstitial - m & VIsSOTto (2000) \\
\hline I. mirini & Novo river - SP & 58 & $11624 m+34 s m$ & pair 1 - interstitial - m & Vissotto (2000) \\
\hline I. mirini & Pardo river, SP & 58 & $11624 m+34 s m$ & pair 1 - interstitial - m & Vissotto (2000) \\
\hline I. mirini & Canta Galo stream, SP & 58 & $11624 m+34 s m$ & pair 1 - interstitial - m & Vissotto (2000) \\
\hline Imparfinis aff. I. schubarti & Canta Galo stream, SP & 58 & $10822 m+18 s m+10 s t+8 a$ & pair 1 - interstitial - $m$ & FENOCCHIO et al. (2003) \\
\hline Imparfinis aff. I. schubarti & Ribeirão Três Bocas, PR & 58 & $10822 m+18 s m+10 s t+8 a$ & pair 1 - interstitial - $m$ & FENOCCHIO et al. (2003) \\
\hline Imparfinis aff. I. schubarti & Tigabi river, PR & 58 & $11628 m+28 s m+2 s t$ & pair 1 - interstitial - m & Stolf et al. (2004) \\
\hline Imparfinis schubarti & Ribeirão das Minhocas, MG & 58 & $11618 m+34 s m+6 s t$ & pair 10 - interstitial -sm & Present Study \\
\hline
\end{tabular}

(SP) São Paulo, (PR) Paraná, (MG) Minas Gerais. * Reported as H. longicauda.

nucleolar organizing region from an interstitial to a terminal position may represent a synapomorphy further grouping $I$. hollandi and I. borodini.

According to Fenocchio et al. (2003), Cetopsorhamdia sp. collected in the River Canta Galo (city of Itirapina, SP, Brazil) has a simple NOR located in the largest pair of metacentric chromosomes and $2 \mathrm{n}=58$. Cetopsorhamdia iheringi Schubart \& Gomes, 1959 (VissotTo et al. 1999) also has 2n = 58 and simple interstitial Ag-NOR in the largest chromosome pair, although that pair is submetacentric. In this last study, a conspicuous heterochromatic block adjacent to the Ag-NOR was also observed. Within the Heptapteridae, both Imparfinis and Cetopsorhamdia belong to the "Nemuroglanis subclade" (Ferraris 1988, Lundberg et al. 1991a, BockMAnn 1994). The absence of these characteristics in heptapterids that are not members of the subclade, such as Rhamdia Bleeker, 1858 and Pimelodella Eigenmann \& Eigenmann, 1888, suggests that they may be apomorphic characters shared at least by these two genera.

The use of the $18 \mathrm{~S}$ rDNA probe confirmed the data obtained with the silver nitrate staining and revealed heteromorphism in the single NOR-bearing chromosome pair in $I$. schubarti. STolf et al. (2004) identified in Imparfinis sp. aff. I. schubarti a pattern identical to the one observed in this study, however with the absence of heteromorphism.

In superior eukaryotes, the $5 \mathrm{~S}$ and $18 \mathrm{~S}$ genes are frequently disposed in separate chromosome pairs (Long \& DAVID 1980, LucChin et al.1993, Drouin \& Moniz de SÁ 1995). This is the most frequent condition in fishes (Martins \& GaleTtI JR 2001) and represents the ancestral state of the chromosomal organization (MarTínez et al. 1996). The synthenic location of the $5 \mathrm{~S}$ and $18 \mathrm{~S}$ rDNA observed in I. schubarti is therefore an apomorphic condition, and further investigation on the distribution of this trait among species of Imparfinis may provide useful phylogenetic data.

The natural distribution of $I$. schubarti comprises the upper Paraná River Basin (BockMann \& Guazzelli 2003, BockManN 2007). However, the transposition of the River Piumhi in the early 1960s introduced several species from the upper Paraná into the São Francisco river basin (Fig. 1) (Moreira-FILHo \& BuckuP 2005). The presence of $I$. schubarti in the region of the transposition channel of the Piumhi River, now belonging to the São Francisco River Basin, emphasizes the importance of cytoge- 
netic and taxonomical studies involving native species of the São Francisco basin, such as Imparfinis minutes (Lütken, 1874). The present study represents a starting point in the evaluation of possible hybridization of such species with I. schubarti.

\section{LITERATURE CITED}

Bertollo, L.A.A.; C.S. TaKahashi \& O. Moreira-Filho. 1978. Cytotaxonomic consideration on Hoplias lacerdae (Pisces, Erythrinidae). Brazilian Journal of Genetics 1: 103-120.

BockManN, F.A. 1994. Description of Mastiglanis asopos, a new pimelodid catfish from northern Brazil, with comments on phylogenetic relationships inside the subfamily Rhamdiinae (Siluriformes: Pimelodidae). Proceedings of the Biological Society of Washington 107: 760-777.

Bockmann, F.A. 2007. Família Heptapteridae, p. 104-109. In: P.A. Buckup; N.A. Menezes \& M.S. Ghazzi (Eds). Catálogo das espécies de peixes de água doce do Brasil. Rio de Janeiro, Museu Nacional, 195p.

Bockmann, F.A. \& G.M. GuazzeluI. 2003. Family Heptapteridae (Heptapterids), p. 406-431. In: R.E. Reis; S.O. Kullander \& C.J. Ferraris Jr (Eds). Checklist of the Freshwater Fishes of South and Central America. Porto Alegre, Edipucrs, 729p.

Castro, R.N. \& L. Casatti. 1997. The fish fauna from a small forest stream of the upper Parana river basin, southeastern Brazil. Ichthyological Exploration of Freshwaters 7: 337352.

Drouin, G. \& M. MonIZ DE SÁ. 1995. The concerted evolution of $5 \mathrm{~S}$ ribossomal genes linked to the repeat units of other multigene families. Molecular Biology and Evolution 12: 481-493.

Fenocchio, A.S.; L.A.C. Bertollo; C.S. Takahashi; A.L. Dias \& A.C. SwarÇA. 2003. Cytogenetic Studies and Correlate Considerations on Rhamdiinae Relationships (Pisces, Siluroidei, Pimelodidae). Cytologia 68: 363-368.

FERRARIS JR, C.J. 1988. Relationships of the neotropical catfish genus Nemuroglanis, with a description of a new species (Osteichthyes: Siluriformes: Pimelodidae). Proceedings of the Biological Society of Washington 101: 509-516.

Ferraris JR, C.J. 1998. Checklist of the Freshwater Fishes of South and Central America. Porto Alegre, Edipucrs, 729p.

Foresti, F.; C. Oliveira \& L.F. Almeida-Toledo. 1993. A method for chromosome preparations from large fish specimens using in-vitro short-term treatment with colchicines. Experientia 49: 810-813.

Hatanaka, T.E. \& P.M. Galetti JR. 2004. Mapping of the $18 \mathrm{~S}$ and 5S ribosomal RNA genes in the fish Prochilodus argenteus, Agassiz, 1829 (Characiformes, Prochilodontidae). Genetica 122: $239-244$.

Howell, W.M. \& D.A. BLACK. 1980. Controlled silver staining of Nucleolus Organizer Regions with protective colloidal developer: a one-step method. Experientia 36: 1014-1015.

Levan, A.; K.E. Fredga \& A.A. Sandberg. 1964. Nomenclature for centromeric position on chromosomes. Hereditas 52: 201-220.
Long, E.O. \& I.B. David. 1980. Repeated genes in eukaryotes. Annual Review of Biochemistry 49: 727-764.

Lucchini, S.; I. Nardi; G. Barsacchi; R. Batistoni \& F. Andronico. 1993. Molecular cytogenetics of the ribossomal $(18 \mathrm{~S}+28 \mathrm{~S}$ and 5S) DNA loci in primitive and advanced urodele amphibians. Genome 36: 762-773.

LundBERG, J.G.; A.H. Bornbush \& F. MAGo-LeCCIO. 1991a. Gladioglanis conquistador n. sp. from Ecuador with Diagnoses of the Subfamilies Rhamdiinae Bleeker and Pseudopimelodinae n. subf. (Siluriformes: Pimelodidae). Copeia 1: 190-209.

Lundberg, J.G.; F. MAGo-Leccio \& P. NASs. 1991b. Exallondontus aguanai, a new genus and species of Pimelodidae (Pisces, Siluriformes) from the deep river channels of South America, and delimitation of the subfamily Pimelodidae. Proceedings of the Biological Society of Washington 104: 840-869.

Margarido, V.P. \& O. Moreira-Filho. 2008. Karyotypic differentiation through chromosome fusion and number reduction in Imparfinis hollandi (Ostariophysi, Heptapteridae). Genetics and Molecular Biology 31: 235-238.

Martínez, J.L.; P. Morán; S. Garcia-Vásquez \& A.M. Pendás. 1996. Chromosomal localization of the major and 5S rRNA genes in the European eel (Anguilla anguilla). Cytogenetics and Cell Genetics 73: 149-152.

Martins, C. \& P.M. Galetti JR. 1999. Chromosomal localization of 5s rDNA genes in Leporinus fish (Anostomidae, Characiformes). Chromosome Research 7: 363-367.

Martins, C. \& P.M. Galetti JR. 2001. Two 5S rDNA arrays in Neotropical fiish species: is it a general rule for fishes? Genetica 111: 439-446.

Moreira-Filho, O. \& P.A. Buckup. 2005. A poorly known case of watershed transposition between the São Francisco and upper Paraná river basins. Neotropical Ichthyology 3: 445-448.

Oliveira, C.; L.F. Almeida-Toledo; F. Foresti; H.A. Britski \& ToledoFilho, S.A. 1988. Chromosome formulae of neotropical freshwater fishes. Revista Brasileira de Genética 11: 577-624.

Oliveira, C. \& A.E. Gosztonyi. 2000. A cytogenetic study of Diplomistes mesembrinus (Teleostei, Siluriformes, Diplomystidae) with a discussion of chromosome evolution in siluriforms. Caryologia 53: 31-37.

DE PINNA, M.C.C. 1998. Phylogenetic relationships of neotropical Siluriformes (Teleostei: Ostariophysi): Historical overview and synthesis of hypotheses, p. 279-330. In: L.R. MALABARBA; R.E. Reis; R.P. VARI; Z.M.S. LuCENA \& C.A.S. LuCENA (Eds). Phylogeny and Classification of Neotropical Fishes. Porto Alegre, Edipucrs, 603p.

Pinkel, D.; T. Straume \& J.W. Gray. 1996. Cytogenetic analysis using quantitative, high-sensitivity, fluorescence hybridization. Proceedings of the National Academy of Science 83: 29342938.

Stolf, R.; A.C. Swarça; L. Giuliano-Caetano \& A.L. Dias. 2004. Analyses of karyotype and nucleolar organizer regions of Imparfinis aff. schubarti (Siluriformes, Pimelodidae) of the Tibagi river basin, Paraná, Brazil. Caryologia 57: 348-352. 
SumNer, A.T. 1972. A simple technique for demonstrating centromeric heterocromatin. Experimental Cell Research 75: 304306.

Vissotto, P.C.; F. Foresti \& C. Oliveira. 1997. A ZZ/ZW sex chromosome system in Imparfinis mirini (Pisces, Siluriformes). Cytologia 62: 61-66.

Submitted: 29.XII.2008; Accepted: 11.XII.2009.

Editorial responsibility: Marcio R. Pie
Vissotto, P.C.; F. Foresti \& C. Oliveira. 1999. Karyotypic characterization of five species of Pimelodidae (Teleostei, Siluriformes). Chromosome Science 3: 1-7.

Vissotto, P.C.; F. Foresti \& C. Oliveira. 2001. Karyotypic characterization of two species of the genus Imparfinis (Teleostei, Siluriformes, Haptapteridae). Chromosome Science 5: 97-103. 